\title{
Sequence diversity in the coat protein gene of Lettuce big-vein associated virus and Mirafiori lettuce big-vein virus infecting lettuce in Brazil.
}

\author{
Márcio Martinello Sanches*, Renate Krause-Sakate and Marcelo Agenor Pavan.
}

Unesp, FCA, Departamento de Produção Vegetal, Rua José Barbosa de Barros, 1780 CEP: 18610-307, Botucatu-SP., Brasil.

* Parte da tese de mestrado do primeiro autor. Projeto financiado pela FAPESP.

Author for correspondence: Renate Krause Sakate, renatekrause@ fca.unesp.br

Data de chegada: 18/12/2006. Aceito para publicação em: 18/01/2007

\section{RESUMO}

Sanches, M.M.; Krause-Sakate, R.; Pavan, M.A. Variabilidade genética na porção codificadora para a proteína capsidial do Lettuce big-vein associated virus e Mirafiori lettuce big-vein virus provenientes de alface no Brasil. Summa Phytopathologica, v.34, n.2, p.175-177, 2008

Lettuce big vein associated virus (LBVaV) e Mirafiori lettuce big vein virus (MLBVV) têm sido encontrados em infecções mistas no Brasil, causando a doença conhecida como engrossamento das nervuras da alface. Análise de parte do gene da proteína capsidial (CP) de isolados brasileiros de LBVaV coletados em alface, indicou que estes possuem identidade superior a $93 \%$ com isolados coletados em diferentes regiões geográficas.
A diversidade genética entre a CP de isolados de MLBVV de alface foi maior comparada às sequências da $\mathrm{CP}$ de $\mathrm{LBVaV}$, com a identidade de aminoácidos variando entre 91 a 100\%. Os isolados brasileiros de MLBVV pertencem ao subgrupo A, com um único sítio de restrição RsaI no gene da proteína capsidial. Não há indicação para uma provável origem geográfica dos isolados brasileiros de MLBVV e LBVaV.

Palavras-chave adicionais: LBVaV, MLBVV, Olpidium brassicae.

\section{ABSTRACT}

Sanches, M.M.; Krause-Sakate, R.; Pavan, M.A. Sequence diversity in the coat protein gene of Lettuce big-vein associated virus and Mirafiori lettuce big-vein virus infecting lettuce in Brazil. Summa Phytopathologica, v.34, n.2, p.175-177, 2008

Lettuce big vein associated virus (LBVaV) and Mirafiori lettuce big vein virus (MLBVV) have been found in mixed infection in Brazil causing the lettuce big vein disease. Analysis of part of the coat protein (CP) gene of Brazilian isolates of LBVaV collected from lettuce, showed at least $93 \%$ amino acid sequence identity with other LBVaV isolates. Genetic diversity among MLBVV CP

Additional keywords: big-vein, LBVaV, MLBVV, Olpidium brassicae. sequences was higher when compared to LBVaV CP sequences, with amino acid sequence identity ranging between $91 \%$ to $100 \%$. Brazilian isolates of MLBVV belong to subgroup A, with one RsaI restriction site on the coat protein gene. There is no indication for a possible geografical origin for the Brazilian isolates of $\mathrm{LBVaV}$ and MLBVV.
Lettuce big vein disease was first described in California (5), and is a soil-borne disease found worldwide (9). The name of the disease refers to the appearance of chlorotic regions surrounding the vascular tissue that confers the aspect of an anomalous vein enlargement, commonly accompanied by severe leaf deformations and growth reductions. The economic importance of the disease is a result of the unsightliness of the lettuce foliage, which depresses market value, delays head formation, decreases head size and reduces the proportion of harvestable plants (13).

The big vein symptoms were historically attributed to Lettuce big-vein associated virus (LBVaV; genus Varicosavirus), formerly known as Lettuce big-vein virus (LBVV), but a causative relationship was never confirmed. According to Roggero et al. (9), the Mirafiori lettuce big-vein virus (MLBVV), formerly known as Mirafiori lettuce virus (MiLV), which belongs to the genus Ophiovirus, was reported to be the causal agent of big-vein disease. LBVaV and MLBVV are both transmitted by the soil-borne fungus Olpidium brassicae (6). The resting spores of the fungus can persist for over 20 years in soil and can retain the ability to transmit the disease for over 15 years (2).

In Brazil the disease was reported on 2003 and its occurence was associated to cooler season (3). Frequently plants exhibiting big vein symptoms are coinfected with both viruses $(3,7,9,11)$, but simple infection by $\mathrm{LBVaV}$ has also been observed, indicating that $\mathrm{LBVaV}$ could also contribute in some manner to the disease $(7,9,11)$.

In order to give additionall knowledge of the big vein disease occurring in Brazil, the coat protein gene from three MLBVV and four $\mathrm{LBVaV}$ isolates collected from lettuce producing areas of São Paulo State, was sequenced and compared with others found in different 


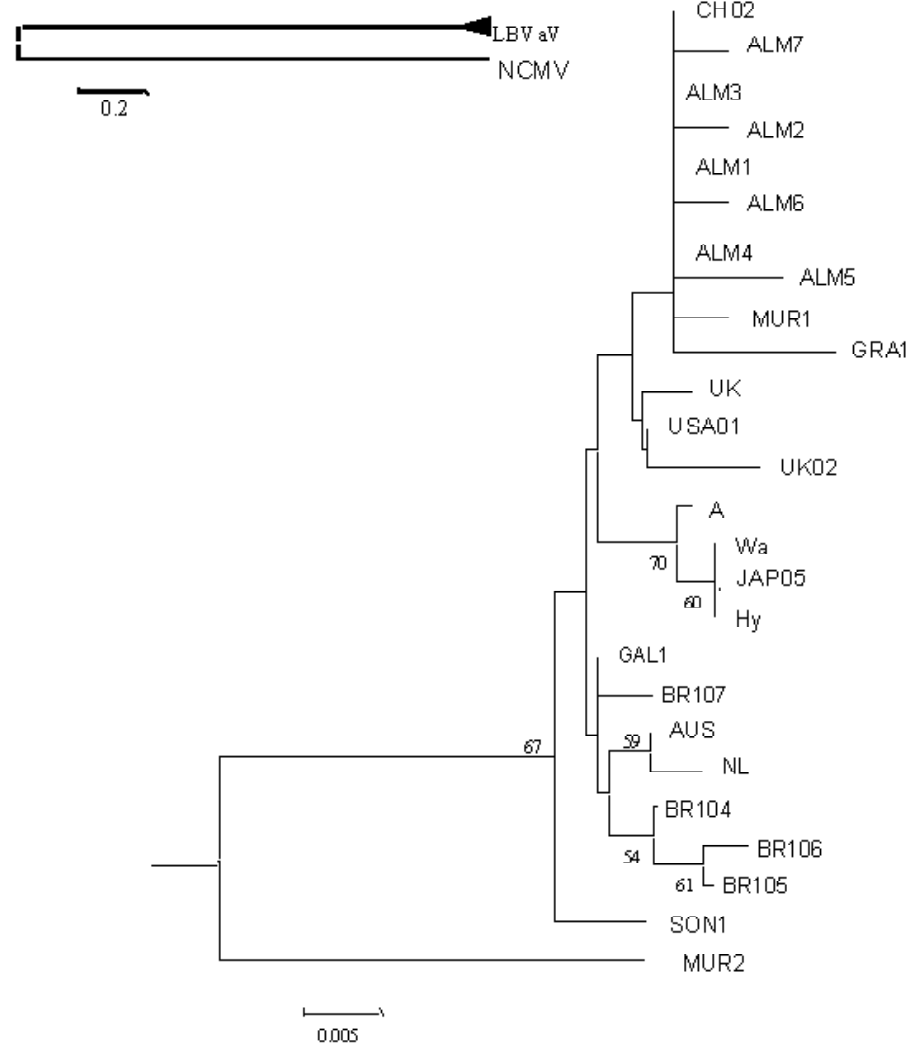

LBVaV

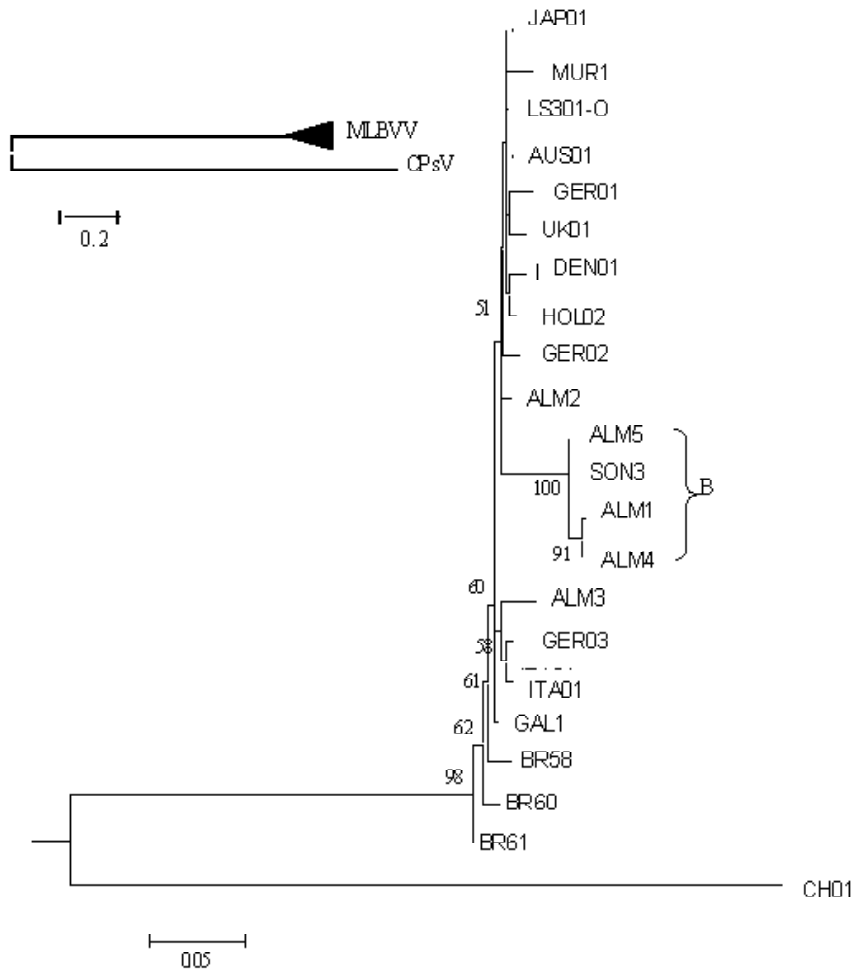

MLBVV

Figure 1. Phylogenetic analysis of Lettuce big vein associated virus (LBVaV) (left) and Mirafiori lettuce big vein virus (MLBVV) (right) isolates based on their CP nucleotide sequences. Trees were constructed with neighbor-joining method with 2000 bootstrap replicates. Internal branches with bootstrap replicates lesser than 50\% were not indicated. Outgroup: Northern cereal mosaic virus (NCMV) (AB030277) for LBVaV and Citrus psorosis virus (CPsV) (AF036338) for MLBVV and its relationship with the isolates of MLBVV from Japan (JAP1, BD418581), Netherlands (LS301-O, AF525935; HOL2 (AY581693), Spain (MUR1, AY366415; GAL1, AY366416; ALM1, AY366417; ALM2, AY366418; ALM3, AY581700; ALM4, AY581701; ALM5, AY581702; SON3, AY839626), Chile (CH 01), Australia (AUS1, AY581696), Denmark (DEN1, AY581692), England (UK1, AY581694), Germany (GER1, AY581695; GER2, AY581697; GER3, AY581698), Italy (ITA1, AY581699), Brazil-Mogi das Cruzes (BR61, DQ530356), Brazil-Campinas (BR60, DQ530357), Brazil-Bauru (BR58, DQ530358) and LBVaV isolates from Japan (Wa, AB190528; Hy, AB190527; A, AB190526; JAP5, AB050272), Netherlands (NL, AY496056), Spain (ALM7, AY581688; MUR1, AY366411; ALM2, AY366413; ALM3, AY581684; ALM4, AY581685; ALM1, AY366414; ALM5, AY581686; GAL1, AY366412; SON1, AY839618; MUR2, AY581691; GRA1, AY581689; ALM6, AY581687), Australia (AUS, AY496055), England (UK2, AY581690; UK, AY496054), Estados Unidos (USA01, AY496053), Chile (CH02), Brazil-Mogi das Cruzes (BR106, DQ530355), Brazil-Campinas (BR104, DQ530353) and Brazil-Bauru (BR105, DQ530354; BR107, DQ530352).

areas of the world.

Old leaf pieces from symptomatic lettuce plants were collected from the lettuce producing areas surrounding the cities of Mogi das Cruzes, Campinas and Bauru, São Paulo State during 2004 and 2005. Total RNA extraction was performed as described by Bertheau et al. (1) using leaves stored at $4^{\circ} \mathrm{C}$. The RT-PCR assay was carried out in a one-step procedure, using the primers pairs MiLVV CP1/CP2 and MiLVV CP2/CP3 and LBVV CP1/CP2 and LBVV CP3/CP4 covering the complete nucleotide sequence of the coat protein of MLBVaV and LBVaV, respectively (10). The RT-PCR was made in a $50 \mathrm{ml}$ reaction volume containing 0,75 U AMV reverse transcriptase (Promega Corp., USA); $5 \mathrm{ml}$ of RNA total as template; $10 \mathrm{ml}$ of Go Taq DNA Polimerase Buffer 5x (Promega Corp., USA); 0,5 mM each of primer pairs; 0,5 mM dNTPs; 1,25 U Go Taq DNA Polimerase (Promega Corp., USA). RT-PCR amplification conditions included a reverse transcription at $42^{\circ} \mathrm{C}$ for $30 \mathrm{~min}$, initial denaturation at $95^{\circ} \mathrm{C}$ for $5 \mathrm{~min}$ followed by 40 cycles of denaturation at $92^{\circ} \mathrm{C}$ for $30 \mathrm{sec}$, annealing at $50-54^{\circ} \mathrm{C}$ for 40 sec, extension at $72^{\circ} \mathrm{C}$ for $40 \mathrm{sec}$ and final extension at $72^{\circ} \mathrm{C}$ for 10 min. For primer pairs MiLV CP1/CP2, LBVV CP1/CP2 and LBVV $\mathrm{CP} 3 / \mathrm{CP} 4$ annealing was performed at $54^{\circ} \mathrm{C}$ and for primer pair $\mathrm{MiLV}$ $\mathrm{CP} 3 / \mathrm{CP} 4$ at $50{ }^{\circ} \mathrm{C}$.

The PCR fragments were purified by Wizard SV Gel and PCR Clean-Up System (Promega Corp., USA) according to manufacturer's recommendations and directly ligated into plasmid pGEM-T Easy Vector (Promega Corp., USA), prior to sequence. Nucleotide and predicted amino acids sequences were aligned using the CLUSTAL W program (12). At aminoacid levels, identities varied from 93\% to $99 \%$ for LBVaV, and 91 to $100 \%$ for MLBVV . Phylogenetic analysis was done using MEGA version 3.1 (www.megasoftware.net) by rooting the trees with the CP gene of the Cytorhabdovirus Northern cereal mosaic virus (NCMV) and the Ophiovirus Citrus psorosis virus $(\mathrm{CPsV})$ for $\mathrm{LBVaV}$ and MLBVaV, respectively. 
Variability in the nucleotide and amino acid sequences of the CP gene of LBVaV isolates from São Paulo State and other countries was low. No correlation of isolates and geographic origin was revealed, although Japanese LBVaV isolates formed a group with $70 \%$ bootstrap support (Figure 1). These results agree with those described by Hayes et al. (4) that the selective pressure to preserve particular biological functions is stronger than adaptation to specific geographic areas.

The variability in the nucleotide and amino acid sequences of the CP gene of MLBVV isolates is higher than variability of LBVaV isolates. Restriction sequence analysis of the coat protein of MLBVaV Brazilian isolates revealed only one RsaI site, indicanting that these isolates belong to the Subgroup A, according to Navarro et al. (8) classification. The MLBVV isolates formed two subgroups with different restriction sites for $R s a \mathrm{I}$, which do not differ in symptom development. The subgroup B is formed only with Spanish isolates (ALM1, ALM4, ALM5 and SON3) previously described by Navarro et al. (8). These results supports the suggestion of Hayes et al. (4) that research on big vein disease in the United States, Europe and Japan will likely be relevant for lettuce production in others areas as well, due to nucleotide sequence conservation among lettuce isolates of these pathogens, including countries on South America. Understanding the nucleotide sequence diversity of MLBVV may represent a contribution for future big-vein research in Brazil.

\section{ACKNOWLEDGEMENTS}

This work was supported by FAPESP (Fundação de Amparo à Pesquisa do Estado de São Paulo), Fellowship 04/15180-5.

\section{REFERENCES}

1. Bertheau, Y.; Frechon, D.; Toth, I.K.; Hyman, L.J. DNA amplification by polymerase chain reaction (PCR). In: Pe rombelon, M.V.M.; Wolff, J.M.Van der (Ed.) Methods for the detection and quantification of Erwinia carotovora subsp. atroseptica on potatoes. Dundee: Scottish Crop Research Institute, 1998.

2. Campbell, R.N. Fungal transmission of plant viruses. Annual Review of Phytopathology, Palo Alto, v. 34, p.87-108, 1996.

3. Colariccio, A.; Chaves, A.L.R.; Eiras, M.; Chagas,C.M.; Roggero,
P. Detection of Varicosavirus and Ophiovirus in lettuce associated with lettuce big-vein symptoms in Brazil. Fitopatologia Brasileira, Brasília, v.30, n.4, p.416-19, 2005.

4. Hayes, R.J.; Wintermantel, W.M.; Nicely, P.A.; Ryder, E.J. Host resistance to Mirafiori lettuce big-vein virus and Lettuce big-vein associ ated virus and virus sequence diversity and frequency in California. Plant Disease, St. Paul, v.90, n.2, p. 233-239, 2006.

5. Jagger, I.C.; Chandler, N. Big Vein, a disease of lettuce. Phytopathology, St. Paul, v. 24, p.1253- 1256, 1934.

6. Lot, H.; Campbell, R.N.; Souche, S.; Milne, R.G.; Roggero, P. Transmission by Olpidium brassicae of Mirafiori lettuce virus and Lettuce big-vein virus, and their Roles in Lettuce Big-Vein Etiology. Phytopathology, St. Paul, v.92, p. 288-293, 2002.

7. Navarro, J.A.; Botella, F.; Maruhenda, A.; Sastre, P.; SanchezPina, M.A.; Pallas, V. Comparative infection progress analysis of Lettuce big-vein virus and Mirafiori lettuce virus in lettuce crops by developed molecular diagnosis techniques. Phytopathology, St. Paul, v. 94, p. 470-477, 2004.

8. Navarro, J.A. ; Torok, V.A.; Vetten, H.J.; Pallas, V. Genetic variability in the coat protein genes of Lettuce big-vein associated virus and Mirafiori lettuce big-vein virus. Archives of Virology, New York, v.150, p.681-694, 2005.

9. Roggero, P. ; Lot, H.; Souche, S.; Lenzi, R.; Milne, R.G. Occurrence of Mirafiori lettuce virus and Lettuce big-vein virus in relation to development of big-vein symptoms in lettuce crops. European Journal of Plant Pathology, Dordrecht, v.109, p. 261-267, 2003.

10. Rosales, M.; Sepulveda, P.; Bruna, A. First Report of Lettuce bigvein virus and Mirafiori lettuce virus in Chile. Plant Disease, St. Paul, v.88, n.11, p.1286, 2004.

11. Sanches, M.M.; Krause-Sakate, R.; Zerbini, F.M.; Rosales, M.; Le Gall, O.; Pavan, M.A. Frequência de Lettuce big-vein associated virus e Mirafiori lettuce big-vein virus em plantas de alface sintomáticas e assintomáticas no Estado de São Paulo. Summa Phytopathologica, Botucatu, v. 33, p. 377-381, 2007.

12. Thompson, J.D.; Higgins, D.G.; Gibson, T.J. CLUSTAL W: Improving the sensitivity of progressive multiple sequence alignment through sequence weighting, position-specific gap penalties and weight matrix choice. Nucleic Acids Research, Oxford, v.22, p. 4673-4680, 1994.

13. Zink, F.W.; Grogan. R.G. The interrelated effects of big vein and market price on the yield of head lettuce. Plant Disease Reporter, Washington, v.38, p.844-846, 1954. 